\title{
An update on genetically modified crops
}

\author{
Andrés R. Schwember \\ Department of Plant Sciences, University of California, Davis, CA 95616-8780, USA
}

\begin{abstract}
A. R. Schwember. 2008. An update on genetically modified crops. Cien. Inv. Agr. 35(3):231250. Genetically modified (GM) crops were introduced in the mid 1990s and two principal transgenic technologies currently dominate the market, herbicide-tolerant (HT) crops and insectresistant crops (Bacillus thuringiensis (Bt) crops). HT crops have simplified weed management practices, reduced crop production costs, and have had positive effects on the environment. However, there are concerns about the potential development of weeds resistant to glyphosate, the main herbicide employed with HT crops. A second major worry associated with the use of HT crops is the potential introgression of genes from GM crops into wild relatives (i.e. gene flow) and its potential impact on natural ecosystems. Bt crops have increased yields and reduced the use of insecticides, providing benefits for human health and the environment. However, the potential development of resistance to the Bt toxin by insect pests and the indirect damage of $\mathrm{Bt}$ toxins to non-target species are major concerns related to their use. Different strategies to mitigate and eliminate the problems associated with the use of GM crops are discussed in the paper. The next step in plant biotechnology is the release of nutritionally-enhanced components in seeds that will benefit humans directly.
\end{abstract}

Key words: Bt crops, gene flow, genetically modified crops, glyphosate, Golden Rice, herbicide-tolerant crops, transgenic crops.

\section{Introduction}

Genetically modified (GM), genetically engineered, or transgenic crops refer to plants produced by the insertion of specific pieces of nucleic acids into the plant's DNA using recombinant DNA technology (i.e. Agrobacterium-mediated transformation or direct gene transfer methods) (Griffiths et al., 2005). This biotechnological approach allows genes to be introduced into a plant genome from any source (i.e., plant, animal, bacterial, fungal) resulting in the potential transfer of a wide range of genetic resources between unrelated species, a major difference compared to traditional plant breeding that is limited to exchange of genetic material only between sexually compatible close relatives of a given plant (Mirkov, 2003).

Received 17 December 2007. Accepted 17 March 2008

${ }^{1}$ Corresponding author: arschwember@ucdavis.edu
An important breakthrough in the development of GM crops occurred when Murai et al. (1983) produced sunflowertissues carrying aseed protein gene from French bean, and these authors were the first to demonstrate the expression of a plant gene after transfer to a taxonomically distinct botanical family. However, more than a decade passed before the release of the first commercial GM crops. In 1994, 'FlavrSavr' fresh tomatoes from Calgene (now Monsanto) and processing tomatoes developed in the United Kingdom (UK) were developed and commercialized. Transgenic techniques were used in these first GM tomato varieties to reduce the activity of a gene encoding polygalacturonase, an enzyme that contributes to cell wall softening during ripening, which slowed down the ripening process and extended the shelf life of GM tomato varieties (Smith et al., 1988). 'FlavrSavr' was shortly withdrawn from the market since the trait was not originally introduced into a suitable genetic background and the tomato did not perform well in commercial production (Slater $e t$ 
al., 2003). The GM processing tomatoes turned out to be much more successful because of the higher solids content compared to conventional varieties, reducing the cost of processing, but most retailers withdrew it in 1999 in response to anti-GM attitudes from consumers (Halford, 2006).

The main introduction of GM crops took place in 1996, when biotechnology-derived herbicidetolerant (HT) and insect-resistant traits were launched into the market in soybean, cotton, corn, and canola (Table 1). These 'input traits' were designed to benefit the farmer directly and aimed to increase productivity per hectare, reduce agrochemical use, decrease production costs, have greater flexibility and efficiencies in production regimes, and improve grower health (Hossain et al., 2004; Huang et al., 2005). However, the recent emergence of herbicide resistant weeds due to the repetitive use of herbicides with the same mode of action in fields of HT crops has posed serious concerns about the sustainability of the weed control provided by HT crops. Another constraint is the potential appearance of weedy relatives resistant to those herbicides by cross pollination to HT crops (Sanvido et al., 2007). There are additional worries about the sustainability and durability of pest resistance as a result of the increasing and uninterrupted use for more than one decade of modified Bacillus thuringiensis toxins $(\mathrm{Bt})$, which confer insect-resistance to GM crops (Bt crops) (Christou et al., 2006).

The objectives of this review are to analyze the current worldwide scenario of the main commercialized GM crops since their introduction in the mid nineties, give an overview about why and how these GM crops were developed, examine the advantages and risks of using these transgenic crops, and explore the new trends encompassing GM crops.

\section{Current status of GM crops}

In 2007, 12 million growers planted around 114 million hectares worldwide of crops having biotechnology-derived traits across 23 countries, with an overall estimated market value of U\$ 6.9 billion (James, 2007) and representing approximately $6 \%$ of worldwide agriculture (Halford, 2006). Global adoption rates for GM crops have grown over $10 \%$ each year since 1996 and are projected to continue to grow at this rate (Figure 1). Countries with the greatest number of biotech crop hectares are (in million of hectares) the USA (57.7), Argentina (19.1), Brazil (15.0), Canada (7.0), India (6.2), and China (3.8). GM soybean continued to be the principal biotech crop in 2007, occupying 58.6 million hectares (51\% of global GM crop area), followed by corn (31\%), cotton (13\%) and canola (5\%) (James, 2007). There are also commercial sugar beet, squash, papaya, tobacco, and carnation GM crops available in the markets of the USA and other countries, although with much smaller areas of cultivation. Since 1996, HT has consistently been the dominant trait followed by insect resistance and stacked (combined) genes for these two traits. In 2007, HT, deployed in soybean, corn, canola, and cotton occupied 63\% (72.2 million hectares) of the global biotech market, with 20.3 million hectares (18\%) planted to Bt crops and 21.8 million hectares (19\%) to the stacked traits of Bt and herbicide tolerance. The stacked trait products were the fastest growing trait group between 2006 and 2007 at $66 \%$ growth, compared with $7 \%$ for insect resistance and 3\% for herbicide tolerance (James, 2007).

The USA has been the world leader in the field of agricultural biotechnology, and the adoption of GM crops has steadily grown in the country (Figure 2). Based on USDA survey data, from 1997 to 2007 HT soybean increased from $17 \%$ to $91 \%$ of the total US soybean area. Plantings of HT cotton expanded from 10\% in 1997 to $70 \%$ in 2007 of the total US cotton area, whereas HT corn reached $52 \%$ of US corn area in 2007 (Fernández-Cornejo, 2007). Regarding the insect-resistant crops, plantings of $\mathrm{Bt}$ corn grew from $8 \%$ of the total US corn area in 1997 to $49 \%$ in 2007 while plantings of Bt cotton expanded from 15\% in 1997 to 59\% in 2007. The adoption of stacked varieties of cotton and corn reached $42 \%$ and $28 \%$ of US plantings in 2007, respectively (FernándezCornejo, 2007). Second-generation products entered the American market in 2003 with the introduction of Bollgard® II cotton (Table 1). Features of second-generation products include the stacked genes, two modes of action (i.e., two 
Table 1. Examples of commercially available genetically modified crops.

\begin{tabular}{|c|c|c|c|c|c|c|}
\hline Crop & $\begin{array}{l}\text { Trait } \\
\text { phenotype }\end{array}$ & $\begin{array}{l}\text { Target } \\
\text { trait gene(s) }\end{array}$ & $\begin{array}{l}\text { Trait } \\
\text { designation }\end{array}$ & $\begin{array}{l}\text { Originating } \\
\text { company }\end{array}$ & $\begin{array}{c}\text { Year of first } \\
\text { commercial sale }\end{array}$ & $\begin{array}{l}\text { Trade } \\
\text { name }\end{array}$ \\
\hline \multirow[t]{5}{*}{ Cotton } & \multirow[t]{3}{*}{$\begin{array}{l}\text { Resistance }{ }^{1} \text { to } \\
\text { lepidopteran }\end{array}$} & crylAc & MON531 & Mosanto & 1996 & $\begin{array}{l}\text { Bollgard } \AA, \\
\text { Ingard® }\end{array}$ \\
\hline & & $\begin{array}{l}\text { cry1Ac, } \\
\text { cry } 2 \mathrm{Ab} 2\end{array}$ & MON15985 & Monsanto & 2003 & Bollgard® II \\
\hline & & $\begin{array}{l}\text { cry1Fa, } \\
\text { cry1Ac, pat }\end{array}$ & $\begin{array}{l}281-24-236 x \\
3006-210-23\end{array}$ & Dow AgroSciences & 2005 & WideStrikeTM \\
\hline & $\begin{array}{l}\text { Resistance to } \\
\text { glyphosate } \\
\text { herbicides }\end{array}$ & CP4 epsps & MOB1445/1698 & Monsanto & 1996 & $\begin{array}{l}\text { Roundup } \\
\text { Ready® }\end{array}$ \\
\hline & $\begin{array}{l}\text { Resistance to } \\
\text { phosphinothricin } \\
\text { herbicides }\end{array}$ & bar & LLCotton 25 & Bayer CropScience & 2005 & LibertyLink $®$ \\
\hline \multirow[t]{8}{*}{ Corn } & \multirow{3}{*}{$\begin{array}{l}\text { Resistance }^{1} \text { to } \\
\text { European corn } \\
\text { borer and other } \\
\text { lepidopteran insects }\end{array}$} & cry1Ab, pat & Bt11 & $\begin{array}{l}\text { Northrup King } \\
\text { (now Syngenta) }\end{array}$ & 1996 & $\begin{array}{l}\text { YieldGard® } \\
\text { Attribute }{ }^{\circledR}\end{array}$ \\
\hline & & crylAb & MON810 & Monsanto & 1997 & $\begin{array}{l}\text { YieldGard® } \\
\text { Corn Borer }\end{array}$ \\
\hline & & cry1F, pat & TC1507 & $\begin{array}{l}\text { Dow AgroSciences; } \\
\text { Pioneer Hi-Bred Intl }\end{array}$ & 2003 & Herculex® I \\
\hline & \multirow[t]{2}{*}{$\begin{array}{l}\text { Resistance }{ }^{1} \text { to } \\
\text { corn rootworm }\end{array}$} & cry3Bb1 & MON863 & Monsanto & 2003 & $\begin{array}{l}\text { YieldGard }{ }^{\circ} \\
\text { Rootworm }\end{array}$ \\
\hline & & $\begin{array}{l}\text { cry1Ab, } \\
\text { cry3Bb1 }\end{array}$ & $\begin{array}{l}\text { MON863 x } \\
\text { MON810 }\end{array}$ & Monsanto & 2005 & YieldGard® Plus \\
\hline & \multirow[t]{2}{*}{$\begin{array}{l}\text { Resistance to } \\
\text { glyphosate }\end{array}$} & Maize epsps & GA21 & DeKalb (now Monsanto) & 1998 & Roundup Ready® \\
\hline & & $\begin{array}{l}\text { Two CP4 } \\
\text { epsps } \\
\text { expression } \\
\text { cassettes }\end{array}$ & NK603 & Monsanto & 2001 & $\begin{array}{l}\text { Roundup Ready }{ }^{\circledR} \\
\text { Corn } 2\end{array}$ \\
\hline & $\begin{array}{l}\text { Resistance to } \\
\text { phosphinothricin } \\
\text { herbicides }\end{array}$ & pat & $\mathrm{T} 14, \mathrm{~T} 25$ & $\begin{array}{l}\text { Aventis } \\
\text { (now Bayer CropScience) }\end{array}$ & 1996 & LibertyLink $®$ \\
\hline Soybean & $\begin{array}{l}\text { Resistance to } \\
\text { glyphosate } \\
\text { herbicides }\end{array}$ & CP 4 epsps & GTS-40-3-2 & Monsanto & 1996 & Roundup Ready® \\
\hline \multirow[t]{2}{*}{ Canola } & $\begin{array}{l}\text { Resistance to } \\
\text { glyphosate } \\
\text { herbicides }\end{array}$ & $\begin{array}{l}\text { CP } 4 \text { epsps, } \\
\text { gox v247 }\end{array}$ & GT73 & Monsanto & 1996 & $\begin{array}{l}\text { Roundup } \\
\text { Ready® }\end{array}$ \\
\hline & $\begin{array}{l}\text { Resistance to } \\
\text { phosphinothricin } \\
\text { herbicides }\end{array}$ & pat & Topas $19 / 2$ & $\begin{array}{l}\text { AgrEvo } \\
\text { (now Bayer CropScience) }\end{array}$ & 1995 & LibertyLink $®$ \\
\hline Alfalfa & $\begin{array}{l}\text { Resistance to } \\
\text { glyphosate } \\
\text { herbicides }\end{array}$ & CP 4 epsps & $\mathrm{J} 101, \mathrm{~J} 163$ & Monsanto & 2005 & Roundup Ready® \\
\hline \multirow[t]{2}{*}{ Squash } & $\begin{array}{l}\text { Resistance }^{1} \text { to } \\
\text { CMV, WMV2 } \\
\text { and ZYMV }\end{array}$ & $\begin{array}{l}\text { Coat protein } \\
\text { genes of, } \\
\text { CMV, WMV2 } \\
\text { and ZYMV }\end{array}$ & $\begin{array}{l}\text { CZW3 } \\
\text { Vegetable Seeds }\end{array}$ & $\begin{array}{l}\text { Asgrow; Semini } \\
\text { (now Monsanto) }\end{array}$ & 1998 & $\begin{array}{l}\text { Destiny III, } \\
\text { Conquerer III, } \\
\text { Liberator III }\end{array}$ \\
\hline & $\begin{array}{l}\text { Resistance }^{1} \text { to } \\
\text { WMV2 and } \\
\text { ZYMV }\end{array}$ & $\begin{array}{l}\text { Coat protein } \\
\text { genes of } \\
\text { WMV2 and } \\
\text { ZYMV }\end{array}$ & ZW-20 & $\begin{array}{l}\text { Asgrow; Semini } \\
\text { Vegetable Seeds } \\
\text { (now Monsanto) }\end{array}$ & 1995 & $\begin{array}{l}\text { Preclude II, } \\
\text { Patriot II, } \\
\text { Declaration II, } \\
\text { Independence II }\end{array}$ \\
\hline Papaya & Resistance $^{1}$ to & $\begin{array}{l}\text { PRSV coat } \\
\text { protein gen } \\
\text { PRSV }\end{array}$ & $\begin{array}{l}55-1 \\
63-1\end{array}$ & $\begin{array}{l}\text { Cornell university; } \\
\text { University of Hawaii, } \\
\text { USDA }\end{array}$ & 1998 & SunUp, Rainbow \\
\hline
\end{tabular}

${ }^{1}$ Many insect resistance and herbicide resistance traits are also available in combinations as stack traits. This table contains representative traits and is not an exhaustive list of all global commercial traits. CMV, Cucumber mosaic virus; PRSV, Papaya ringspot virus; WMV2, Watermelon mosaic virus; ZYMV, Zucchini yellow mosaic virus (Castle et al., 2006). Reproduced with permission of the publisher. 


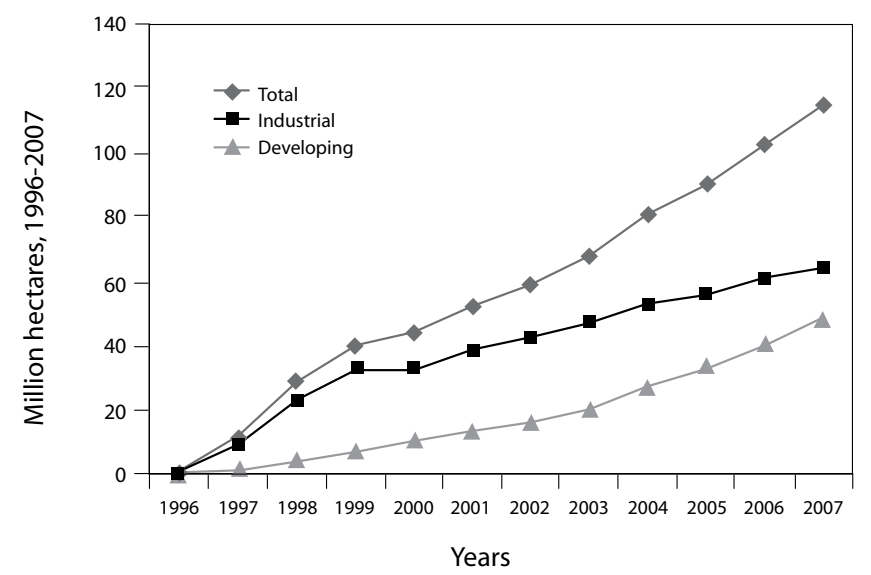

Figure 1. Worldwide grown area of transgenic crops between 1996 and 2007. Increase of 12\%, 12.3 million hectares (30 million acres) between 2006 and 2007.

different Bt genes combined in one product) for improved insect resistance management, and enhanced performance of the traits (i.e., increased spectrum of the target insects). For example, Widestrike ${ }^{\mathrm{TM}}$ cotton and YieldGard ${ }^{\circledR}$ Plus corn are recently released products with stacked Bt gene traits (Castle et al., 2006).

\section{Commercialized GM crops}

\section{Herbicide-tolerant (HT) crops}

HT GM crops were developed to simplify weed management and reduce the associated costs
(Gianessi, 2005). The most successful HT traits introduced to date have enabled GM crops to grow in the presence of foliar-applied, broadspectrum and non-selective herbicides, such as glyphosate and glufosinate. Both compounds are amino acid analogues that have molecular targets in the amino acid biosynthetic pathways (Slater et al., 2003).

Glyphosate is the only herbicide that acts by blocking the shikimate pathway though specific inhibition of the enzyme 5-enolpyruvylshikimate-3-phosphate synthase (EPSPS) (Figure 3). The inhibition of EPSPS impairs

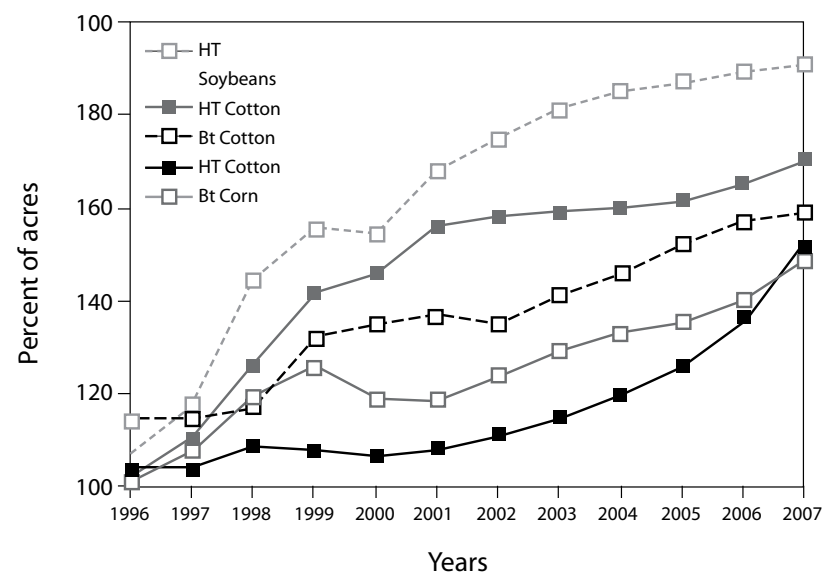

Figure 2. Adoption of transgenic crops grows steadily in the USA. Reproduced with permission of the author. 
the biosynthesis of aromatic amino acids and causes misregulation of the shikimate pathway (Duke et al., 2003), affecting normal plant growth. The development of glyphosateresistant crops (GRCs) utilized the CP4 gene from Agrobacterium sp., which encodes a glyphosate-resistant form of EPSPS, initially introduced in soybean (Padgette et al., 1996). The vast majority of the commercial GRCs on the market today contain the CP4 EPSPS gene that confers glyphosate resistance (Dill, 2005). Glyphosate-resistant canola also contains a gene that encodes a glyphosate oxireductase (GOX) from Ochrobactrum anthropi. This enzyme degrades glyphosate to glyoxylate, a safe and ubiquitous natural product, and aminomethylphosphonate (AMPA), a non-toxic compound (Duke, 2005).

Glufosinate (or phosphinothricin) is a competitive inhibitor of glutamine synthetase, an enzyme

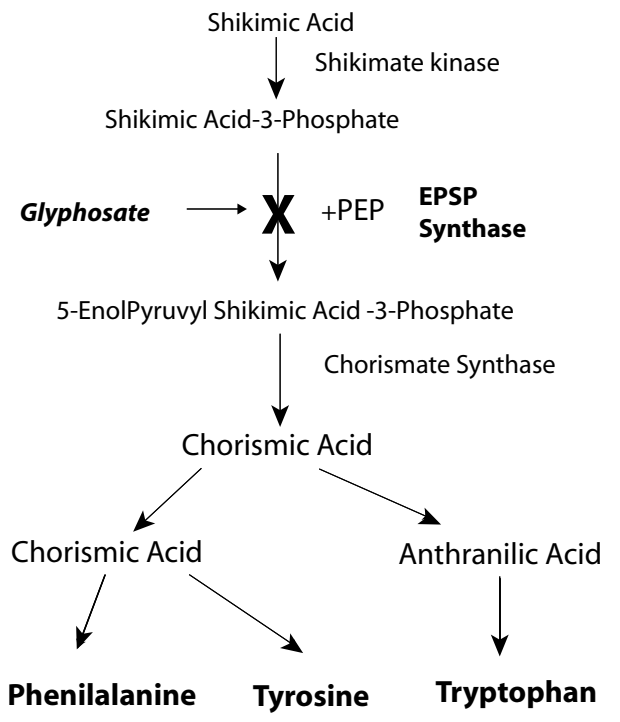

Figure 3. Glyphosate mode of action (Dill, 2005). Three basic biotechnological strategies have been evaluated in order to introduce glyphosate resistance into crops species: (1) Over-expression of the sensitive target enzyme, (2) Detoxification of the glyphosate molecule, and (3) Expression of an insensitive form of the target enzyme. This last strategy has been the most successful in glyphosate-resistant crops, in which the CP4 gene from Agrobacterium sp. encodes a glyphosate-resistant form of EPSPS (Dill, 2005). required for the assimilation of nitrogen into the amino acid glutamine. The bar gene used to produce plants resistant to glufosinate was isolated from the bacterium Streptomyces hygroscopicus and encodes a phosphinothricin acetyl transferase (PAT), an enzyme that detoxifies the herbicide through acylation (Thompson et al., 1987). Many crop species have been successfully transformed with this gene. However, since 1997, only glufosinate-resistant canola, cotton, and corn have been introduced in the USA with moderate success. Glufosinateresistant canola has been particularly successful in Canada (Halford, 2006).

There are several health and environmental benefits associated with the use of glyphosate and glufosinate, as opposed to other chemical herbicides. Both compounds are considered more toxicologically benign than many of the herbicides they replace (Ebert et al., 1990; Williams et al., 2000) due to their relatively short soil half-lives and low mobility to ground or surface water (Duke et al., 2003). In a comprehensive review, Cerdeira and Duke (2006) concluded that the environmental effects of glyphosate on contamination of water, air, soil and non-target organisms are minimal relative to some of the herbicides they replace. In addition, the authors gave extensive evidence that no risks have been found with food, feed safety, or nutritional value in products from currently available glyphosate-resistant crops (GRCs). However, the drift of glyphosate to nontarget plants represents a direct environmental impact (Ellis et al., 2003), which is a problem associated with all foliar-applied herbicides.

One of the most significant environmental benefits of using glyphosate and glufosinate on HT crops has been the rapid conversion to reduced-, minimum- and no-tillage agriculture (Cerdeira and Duke, 2006). In conventional agriculture, mechanical cultivation and incorporation of soil-applied herbicides have been important components of weed management, resulting in loss of topsoil with sometimes irreversible environmental damage. In contrast, these practices are less utilized with foliar-applied compounds (i.e., glyphosate and glufosinate), which kill almost all weeds without tillage. Recently, the University of 
São Paulo in Brazil reported that growing HT soybeans with conventional tillage produced topsoil losses of 1.2 tons per hectare, whereas the glyphosate-resistant soybean planted with no-till practices shrank soil losses to 0.2 tons per hectare, a reduction of more than $80 \%$ with respect to conventional tilling practices (Service, 2007). Glyphosate-resistant soybeans have been very instrumental in the fast conversion to minimum tillage agriculture in the USA, and glyphosate-resistant cotton has contributed to the introduction of minimumtillage cotton (Carpenter and Gianessi, 1999). Furthermore, it has been estimated that complete conversion to no-till can save as much as 53 literha $^{-1}$ in fuel alone, depending upon the number of trips eliminated from production practices (Dill, 2005). The use of glyphosate in GRCs can eliminate the need for cultivation for weed control, allowing growers to reduce row spacing when planting soybeans from 76 to 33 $\mathrm{cm}$ and less. This effectively provides earlier and faster canopy closure by the crop, which further reduces weed competition (Dill, 2005).

The appearance and spread of HT weeds as a result of the cultivation of HT crops have been an important concern for growers, environmentalists and scientists. HT crops can influence herbicide-resistant weeds in several ways: (i) naturally HT weed species can replace those species effectively controlled by the herbicide employed with the resistant crop; (ii) the herbicide utilized with the resistant crop can exert strong selection pressure on weed species, causing the appearance of resistant biotypes; and (iii) the HT crop could become a persistent weed in a different crop system. However, these issues are not new to growers and pose no more environmental problems than those occurring since herbicides were introduced in the middle of the last century (Duke, 2005). To date between eleven (Heap et al., 2006) and twelve (Service, 2007) species of weeds have evolved resistance to glyphosate, although only three of these cases (Conyza canadensis, Ambrosia artemisiifolia, and Amaranthus palmeri) have been associated with GRCs, ten years after their introduction (Cerdeira and Duke, 2006). There are new evolved glyphosate-resistant species of Conyza, Ambrosia and Lolium that have been recently reported in the USA. Likewise, in areas of transgenic glyphosate-resistant crops in Argentina and Brazil, there are now evolved glyphosate-resistant populations of Sorghum halepense and Euphorbia heterophylla, respectively (Powles, 2008). The scale of the occurrence of glyphosate-resistant weeds remains small. Nevertheless, agricultural experts worry that an epidemic of glyphosate-resistant weeds might start in the short term and become a problem (Service, 2007; Powles, 2008).

Introgression (gene flow) of herbicide tolerance transgenes from GM crops into wild relatives has the potential to exacerbate problems with existing weed species in HT crops or to increase the aggressiveness of those species that are not generally considered weeds (Sanvido et al., 2007). This has been considered a legitimate concern of environmentalists and an unalterable effect that GM crops might cause (Duke, 2005). Studies show that transgenes for herbicide resistance are almost certain to move from herbicide-resistant canola to weedy relatives (Légère, 2005), and transgene flow from cultivated rice to its wild relatives has also been documented (Chen et al., 2004). Gene flow from glyphosate-resistant creeping bentgrass (Agrostis stolonifera) has caused additional concerns (Watrud et al., 2004). In summary, gene flow has to be considered a legitimate limitation of GM crops and will be further discussed below.

There has been controversy whether the introduction of HT crops reduced the amount of applied herbicide. Overall, several studies support a small but statistically significant reduction in herbicide use after the adoption of HT crops (Sanvido et al., 2007).

\section{Insect resistance}

The insecticidal properties of the parasporal crystal (protein) of Bacillus thuringiensis (Bt) have been used as an alternative to conventional insecticides for around 60 years and have been the principal insect resistance GM technology employed to date. Bacillus thuringiensis is a ubiquitous soil bacterium that synthesizes proteins with insecticidal properties ( $\delta$-endotoxins or crystal (Cry) proteins) characterized by a relatively narrow range of 
activity. Bt crystal proteins are ingested by insects and subsequently dissolved in the insect midgut under alkaline conditions, resulting in a protoxin of $\sim 130 \mathrm{kDa}$. The protoxins are subsequently trimmed by gut proteases to an N-terminal, 65-70 kDa truncated form, which represents the activated toxin. The toxin binds to specific receptors on the cell membranes of the midgut epithelial cells, inserts itself into the membrane, and forms membrane pores that kill the epithelial cells (and eventually the insect) by osmotic lysis (Knowles and Dow, 1993; de Maagd et al., 1999). Toxicity can be correlated with the number and type of receptors of the target insect species. Resistant insects show alterations in the receptor that binds to the toxin (Van Rie et al., 1990; Tabashnik, 1994).

Bt crystal proteins are part of a large and growing protein family (around 410 toxins, Crickmore et al. (2007)) and their high selectivity is to a large extent determined by the toxin-receptor interaction (Van Rie et al., 1990). The members of the Cry gene family were originally grouped in subfamilies according to their selectivity for members of the insect families Lepidoptera (moths and caterpillars), Diptera (flies and mosquitoes), and Coleoptera (beetles) (Höfte and Whiteley, 1989), which are the primary targets of the Bt toxins (MacIntosh et al., 1990). The current nomenclature is based solely on amino acid identity and removes the necessity for researchers to bioassay each new toxin against a growing series of organisms (Crickmore et al., 2007). Due to the high specificity of the toxin, Bt crops have resulted in no significant risk to human health and the environment compared with the chemical alternatives (Mendelsohn et al., 2003).

Yield increases of $\mathrm{Bt}$ crops compared to conventional varieties have varied depending upon the plant species and the geographic location. In the case of $\mathrm{Bt}$ cotton in India, insecticide applications were reduced $70 \%$ leading to savings of up to U\$30 per hectare in insecticide costs, and an 80-87\% increase in harvested cotton in 157 farms (Qaim and Zilberman, 2003). More than $80 \%$ reduction in pesticide applications in Bt cotton fields has been reported in China, and the proportion of growers with pesticide poisoning was reduced from $22 \%$ to less than $5 \%$ based on a survey made in 1999 (Huang et al., 2002). In the Yellow River cotton-growing region in northern China, over 4 million small farmers have exhibited comparable results in insecticide use reduction (Pray et al., 2002). In pre-commercialization trials, Bt rice has also shown benefits to small and poor farm households in China with 6-9\% higher crop yields and $80 \%$ reduction in pesticide use (Huang et al., 2005). The yield advantages of Bt crops relative to non-transgenic crops are less pronounced in developed countries such as the USA, where yield increases are less than $10 \%$ for Bt cotton and Bt corn, as insect pests already are largely controlled through use of other insecticides (Lauer and Wedberg, 1999; Carpenter et al., 2002). However, the environmental and economic gains of pesticide savings and reduced effort for insect control are well documented in the literature, such as the case of Bt cotton grown and evaluated in 81 commercial fields in Arizona (USA) (Cattaneo et al., 2006). In this study, transgenic and nontransgenic cotton had similar yields overall, largely because higher insecticide use with non-transgenic cotton improved control of key pests. Another study conducted by FAO (2004) revealed that the average number of insecticide applications in the USA used against the budworm-bollworm complex decreased from 4.6 in 1992-1995 to 0.8 in 1999-2001, largely owing to the introduction of Bt cotton.

The potential development of resistance to the $\mathrm{Bt}$ toxin is the major concern related to the use of Bt crops. The diamondback moth (Plutella xylostella) is the only pest to have evolved resistance to $\mathrm{Bt}$ sprays used by organic growers, but no insect pests to date have evolved resistance to transgenic Bt crops in the field (Fox, 2003; Ferry et al., 2006). This has been supported by an eight-year monitoring study (1997-2004) of pink bollworm resistance to Bt toxin with laboratory assays of strains derived annually from 10-17 cotton fields in Arizona. No net increase in the mean frequency of bollworm resistance to Bt toxin was observed (Tabashnik et al., 2005). Likewise, a large-scale study carried out in Bt corn fields in Spain did not identify any resistant corn borers (Ostrinia nubilalis and Sesamia nonagrioides) over a five-year period (Farinós et al., 2004). 
Several strategies have been proposed to maintain durable crop resistance to insects in the field, including a high level of transgene expression, cultivation of multilines containing different insect resistance genes, transgene pyramiding, cultivation of susceptible plants for insect refuge, and plant tissue-specific expression of transgenes (Roush, 1998). An accepted and successful method used in real field conditions for preventing the development of resistance to Bt crops in insect pests has been the 'high-dose/ refuge strategy', in which the transgene must be expressed highly enough to kill almost all of the susceptible insects. In this case, up to $80 \%$ of the total area is dedicated to the cultivation of non-Bt crops that are fully susceptible to the insect pests, depending upon the region, the type of Bt gene, and other transgenic crops grown in the region. The refuge plants serve to maintain a population of the pest that does not carry any resistance mutations and can 'dilute out' a potential resistance allele (Christou et al., 2006). However, there is scientific evidence that argues against the need of refuges in the context of resistance management (Gressel, 2005), whereas more recent data corroborates the overall effectiveness of the refuges to delay resistance (Tabashnik et al., 2008). Failure to adhere strictly to the refuge strategy for resistance management, which is likely to occur with less controlled and more widespread use of transgenic crops, will not necessarily lead to rapid breakdown in the usefulness of Bt crops. Studies have shown pollen-mediated gene flow up to $31 \mathrm{~m}$ from Bt corn that caused low to moderate $\mathrm{Bt}$ toxin levels in kernels of non-Bt corn refuge plants (Chilcutt and Tabashnik, 2004). The authors of the study suggested that guidelines should be revised in order to reduce gene flow between $\mathrm{Bt}$ crops and refuge plants.

The expression of two dissimilar Bt toxin genes represents another effective strategy to delay the development of resistant insect ('transgene pyramiding') (Roush, 1998). The simultaneous introduction of three genes expressing insecticidal proteins (CrylAc, Cry2A, and $G n a$ ) into rice to control three major pests (rice leaf folder, yellow stemborer and the brown planthopper) imparted more resistance than combinations of only two of these transgenes (Bano-Maqbool et al., 2001). Another study of transgene pyramiding showed that transgenic cotton containing two Bt genes (CrylAc and $C r y 2 A b)$ performed better than either the single gene CrylAc or the Cry2Ab transgenic cotton (Jackson et al., 2004).

The effect of insect-resistant crops on nontarget insects has been a controversial issue related to the use of $\mathrm{Bt}$ crops. Scientists at Cornell University reported that the larvae of Monarch butterflies fed on milkweed leaves covered in pollen from $\mathrm{Bt}$ corn grew slower and were smaller than those on control leaves under laboratory conditions (Losey et al., 1999). Theoretically, Bt crops should not represent any risk to Monarch larvae, since they feed only on milkweed leaves (Slater et al., 2003). However, there is the potential for the larvae to come into contact with GM corn pollen that spreads to milkweed surrounding $\mathrm{Bt}$ corn fields. The paper sparked off considerable public concern in the USA. A major research collaboration between six groups in the USA and Canada studied the Bt pollen toxicity in more detail, and investigated the likelihood of exposure of monarch caterpillars to $\mathrm{Bt}$ corn pollen under natural conditions (Sears et al., 2001). This two-year study concluded that the impact of $\mathrm{Bt}$ corn pollen from current commercial hybrids on Monarch butterfly populations was very low. Moreover, a metaanalysis of 42 field experiments indicated that non-target invertebrates were generally more abundant in Bt cotton and Bt corn fields than in non-transgenic fields managed with insecticides (Marvier et al., 2007). Since Bt-transgenic varieties can lead to substantial reductions in insecticide use under growing conditions, Bt crops can contribute to integrated pest management systems with a strong biological control component (Romeis et al., 2006).

\section{Virus resistance}

Abel et al. (1986) reported that transgenic tobacco expressing the coat protein $(\mathrm{CP})$ gene of Tobacco mosaic virus (TMV) was resistant to TMV, which spurred the development of virusresistant transgenic crops. Since then, the initial hope that pathogen-derived resistance (Sanford and Johnson, 1985) might be a practical way to control plant viruses has been firmly established 
and applied to many viruses and crops (Beachy, 1997). Efficient protocols have resulted from technical improvements in transgene engineering, in transformation of a variety of crops, and in the understanding of the mechanisms of resistance. However, the commercial potential has not yet been realized since only three virusresistant crops have reached the marketplace in the USA (Gonsalves et al., 2006).

One approach for achieving virus resistance is based on the phenomenon of cross protection, in which infection by a mild strain of a virus induces resistance to subsequent infection by a more virulent strain. This phenomenon was reproduced constitutively in a GM plant by expressing a transgene encoding a viral $\mathrm{CP}$, and was used in the papaya industry in Hawaii due to an epidemic of Papaya ringpost virus (PRSV) in the nineties (Gonsalves, 1998; Ferreira et al., 2002). This approach was effective in protecting against the severe strains of PRSV, but produced severe symptoms on certain cultivars, such as 'Sunrise', and thus did not receive widespread use (Pitz et al., 1994). However, one mild strain of PRSV was later used as the source of CP for the PRSV-resistant transgenic papaya currently commercialized in Hawaii (Gonsalves et al., 2006).

Another approach uses antisense or cosuppression techniques, which consist in inserting a complementary version of the target gene in an antisense orientation to reduce the amount of the viral protein when the virus infects a plant. For example, a GM potato virusresistant variety carrying a replicase gene from Potato leaf role virus (PLRV) in combination with the Bt insect-resistance trait has been engineered. This technology has being applied to achieve resistance to other plant viruses, such as the resistance to Potato tuber necrotic ringspot virus in potatoes (Racman et al., 2001). Currently, transgene-mediated RNA silencing and generation of small interfering RNAs appear to be primary mechanisms that confer resistance to plant viruses (Sudarshana et al., 2006; Prins et al., 2008).

Extensive safety assessment studies have been carried out over the past 15 years involving virusresistant transgenic plants. Overall, no health or environmental risks have been reported. An ongoing research priority is the assessment of risks related to potential gene flow from virusresistant GM crops to wild relatives (Fuchs and Gonsalves, 2007). For example, the movement of transgenes from a virus-resistant transgenic squash to its wild relative, Cucurbita pepo spp. ovifera var. texana, was documented in experimental field settings (Fuchs et al., 2004).

\section{New developments and trends}

Duke (2005) predicts an increase in the adoption of some existing herbicide-tolerant (HT) crops worldwide, but not the rapid growth that we have seen during the first decade of their availability. Furthermore, although the public reluctance to accept HT crops is not predicted to change in the near future, their neutral and/or favorable environmental effects seem to be causing a shift toward governmental approval of HT crops in some geographic areas. The introduction of a large number of new HT crops over the next 5 years is not expected (Duke, 2005).

Resistance to dicamba has been recently developed (Behrens et al., 2007). Dicamba, an auxin-type herbicide, is a widely used, low-cost, environmentally friendly herbicide that does not persist in soils and shows little or no toxicity to wildlife and humans (Stevens and Sumner, 1991). Behrens et al. (2007) isolated a bacterial gene, DMO (dicamba monooxygenase), that encodes a Rieske non-heme monooxygenase. Transgenic plants expressing $D M O$ are capable of inactivating dicamba. Tobacco, tomato, soybean, and Arabidopsis plants containing the $D M O$ gene were fully resistant to treatments with dicamba at the normal application rates and up to 20 times these levels (i.e., 5.6 $\mathrm{kg} \mathrm{ha}^{-1}$ ), without significant herbicide damage symptoms. Behrens et al. (2007) speculate about the potential combination in the future of the dicamba resistance gene with the glyphosate resistance gene in order to allow growers to alternate applications between both herbicides or to use mixtures of the two herbicides together. In either case, appearance of weeds resistant to either glyphosate or dicamba would be greatly suppressed. The possibility of using two different herbicides before sowing or at a variety of time points during crop development 
would allow a more flexible weed control. Additionally, dicamba-resistant crops would further encourage the use of conservation tillage practices with all the positive consequences discussed above.

The area devoted to growing GM crops expressing insecticidal Cry proteins derived from Bacillus thruringiensis (Bt) has increased steadily since their introduction one decade ago (Romeis et al., 2006). The most likely tendency is that new transgenic plants expressing novel Cry or other insecticidal proteins, stacked genes or fusion proteins will increase in importance in the coming years (Bates et al., 2005). Plants might be introduced in the future that express multiple novel insecticidal proteins, such as the Vip (vegetative insecticidal proteins) produced by Bacillus thuringiensis during its vegetative growth, imparting a wider spectrum of pest control (Yu et al., 1997; de Maagd et al., 2003).

The use of synergists has become one strategy to increase Bt Cry protein toxicity and to overcome and delay insect resistance to this biopesticide (Tabashnik, 1994). For example, a fragment of a toxin-binding cadherin (CR12MPED peptide) has the potential to increase the control of lepidopteran pests by Cry1A toxins. This synergist is a good candidate for development of a more effective strategy to control Lepidopteran pests that are presently not being efficiently controlled by Bt crops, such as the case of cotton bollworm (Helicoverpa zea) (Chen et al., 2007).

Other non-conventional sources for insect resistance are Photorhabdus and Xenorhabdus bacteria, which are symbionts of certain types of nematodes. They cause lethal septicemia in the insect, whose tissues are used as nutrients by the nematode (Chattopadhyay et al., 2004). Considerable progress has been made in the identification of several toxin genes from these two bacteria (Williamson and Kaya, 2003).

Although constitutive expression of insecticidal transgenes has provided high levels of resistance in crop plants, tissue-specific or inducible expression might be desirable under some circumstances. For instance, the novel strategy 'within-plant refuge' has been developed using inducible promoters. In this approach, the transgenic plant itself can serve as a refuge as long as either the expression of the insecticidal gene is not induced or the induction wears off (Bates et al., 2005).

Mehlo et al. (2005) engineered plants with a fusion protein combining the $\delta$-endotoxin CrylAc with the galactose-binding domain of the non-toxic ricin B-chain (RB). Transgenic rice and corn plants designed to express the fusion protein (BtRB) were significantly more toxic in insect bioassays than those containing the $\mathrm{Bt}$ gene alone, due to increased number of potential fusion protein-receptor interactions at the molecular level in target insects.

Transgenic plants overexpressing protease inhibitors (PIs) that affect the insect digestive system have to date shown marginal effectiveness against insect pests (Christou et al., 2006). However, the use of novel inhibitors, such as the barley trypsin inhibitor (Alfonso-Rubi et al., 2003), synthetic constructs containing multiple inhibitors (Outchkourov et al., 2004), equistatin from sea anemone (Gruden et al., 1998), other cystatins (Martínez et al., 2005), and lectins (Zhu-Salzman et al., 2003) might prove useful.

Triple-stack traits (dual Bt genes combined with glyphosate or glufosinate resistance) are likely to replace many of the single-trait products (Castle et al., 2006). However, this poses the challenge of how multiple genes can be transferred into the same plant genome, giving rise to technical and regulatory limitations. One possibility for overcoming these restrictions is to focus on the plant plastome, i.e., the chloroplast genome. Engineering the plastome represents an exciting development of modern plant biotechnology (Daniell and Dhingra, 2002; Slater et al., 2003; Svab and Maliga, 2007). First, chloroplast genes are, like prokaryotic genes, often found in operons, where one promoter regulates the expression of a group of genes. Therefore, a group of foreign genes, organized in an operon, can be introduced under the control of a single promoter. There are several important advantages associated with plastome transformation: (i) all the genes are expressed at similar levels; (ii) high levels of transgene expression and foreign protein 
accumulation are relatively common with chloroplast transformation, thanks to the co-existence of multiple copies of genomes $(>50)$ per chloroplast and the presence of 50 or more chloroplasts per plant cell; (iii) gene silencing does not seem to be a problem; (iv) homologous recombination allows transgenes to be inserted precisely into the chloroplast genome; (v) antibiotic resistance genes do not need to be used as selectable markers or they can be easily excised (Daniell et al., 2001); (vi) cytotoxicity of the foreign protein seems to be less a problem than with nuclear transformation (Slater et al., 2003). Although the technology to obtain marker-free transplastomic plants is available, no transplastomic crops are yet grown commercially. One reason is slow implementation of the tissue culture-based plastid transformation technology outside the group of Solanaceous species, although recently genetically stable transplastomic variants have been obtained in a diverse group of species, including cauliflower, cotton, soybean, lettuce, and poplar. The cereal crops wheat, corn and rice continue to be recalcitrant to plastid transformation (Lutz and Maliga, 2007).

Apart from herbicide-tolerant and insectresistant GM crops, other genetically engineered agronomic traits are currently being developed, such as fungal resistance (Rommens and Kishore, 2000; Dangl and Jones, 2001; Mondal et al., 2007; Ohsato et al., 2007), drought tolerance (Shou et al., 2004; Dezar et al., 2005; Brini et al., 2007), salt tolerance (Zhang and Blumwald, 2001; Zhang et al., 2001; Flowers, 2004; Brini et al., 2007), and nematode resistance (Williamson, 1998; Huang et al., 2006).

Another exciting field of modern plant biotechnology is represented by the enhancement of crop nutritional properties through genetic modification (Rein and Herbers, 2006). There are multiple nutritional advances underway and this review focuses on two representative examples that illustrate the potential impact of this technology.

Carotenoids are a group of plant pigments important in the human diet that serve as the only precursors of vitamin A. Some carotenoids, most importantly $\beta$-carotene, are cleaved to vitamin $\mathrm{A}$ and are referred to as provitamin A (Yeum and Russell, 2002). Vitamin A deficiency, a major problem in parts of the developing world, can result in permanent blindness and increased susceptibility to infectious diseases (West and Darnton-Hill, 2001). Since no rice cultivars produce provitamin $\mathrm{A}$ in the endosperm, recombinant technologies related to GM crops, rather that conventional plant breeding, were required to engineer rice with $\beta$-carotene, called 'Golden Rice' (Ye et al., 2000). Three genes were used (i.e., psy, lcy from daffodil and crtI from bacteria) to enable the biosynthesis of provitamin A in the endosperm of GM rice. However, the work was somewhat limited by the low levels of carotenoids accumulated $\left(1.6 \mu \mathrm{g} \cdot \mathrm{g}^{-1}\right.$ carotenoid in the endosperm). Paine et al. (2005) hypothesized that the daffodil gene encoding phytoene synthase ( $p s y$ ) was the limiting step in $\beta$-carotene accumulation. Through systematic testing of other plant psy genes, they identified a psy from corn that considerably increased carotenoid accumulation in a model plant system. When expressed in rice, this 'Golden Rice 2' accumulated total carotenoids of up to $37 \mu \mathrm{g} \cdot \mathrm{g}^{-1}$, or a 23 -fold increase compared to the original Golden Rice. This translates to delivering $50 \%$ of the children's Recommended Daily Allowance (RDA) in $72 \mathrm{~g}$ of dry new 'Golden Rice 2' (Paine et al., 2005). Recently, the accumulation of carotenoids was further increased and engineered in GM potatoes ('Golden potatoes'). Assuming a $\beta$-carotene to retinol conversion of $6: 1$, this newly developed GM crop is sufficient to provide $50 \%$ of the RDA of vitamin A with $250 \mathrm{~g}$ (fresh weight) of 'golden potatoes' (Diretto et al., 2007).

Genetic engineering of new storage oils and fats has produced oil crop plants with fatty acid compositions, many of which are unattainable or difficult to obtain by plant breeding alone. The combination of classical breeding methods with molecular techniques provides new ways for designing oils for food and industrial uses. Alterations in the position and number of carbon double bonds, variation in fatty acid chain length, and the introduction of desired functional groups have already been achieved in model systems (Töpfer et al., 1995). For example, lauric acid (12:0), which is used in a variety of cosmetics and other products, is derived primarily from palm and coconut oil. 
However, by inserting into rapeseed a specific lauroyl-ACP thioesterase gene derived from the bay tree, scientists at Calgene were able to increase lauric acid production to around $40 \%$ of the total fatty acids, compared with $0.1 \%$ in unmodified oilseed rape (Halford, 2006). Similarly, Calgene scientists were able to block the activity of a desaturase in rapeseed that converts stearic acid (18:0) to oleic acid (18:1), resulting in a high-stearic acid oil useful in margarines. In addition, there is considerable potential in the production of a very high $(>90 \%)$ oleic acid oil for food purposes and as uniform oleochemical feed-stock. Conventional breeding has produced mutant oilseed rape lines with oleic acid content close to $80 \%$, but attempts to increase this level have resulted in plants with poor cold tolerance, presumably as a result of the lack of unsaturated fatty acids in their cellular membranes. Antisense and cosuppression techniques to reduce expression of a specific desaturase in the seeds of GM oilseed rape have, however, raised the oleic acid levels up to $88 \%$, without affecting cold tolerance (Slater et al., 2003). Similar experiments in soybean seeds by DuPont increased the oleic acid level from $20 \%$ (non-GM soybean) to $80 \%$ (GM soybean) (Halford, 2006). Another example that is nearing commercialization is the development of omega-3 fatty acids derived from GM crops. They provide the healthbeneficial effects of long-chain polyunsaturated fatty acids found in fish oils (Graham et al., 2007). These genetically engineered oils were developed since oil-seed species do not synthesize these products naturally and because of the significant reduction in fish oil consumption in recent years (Qi et al., 2004).

\section{Discussion and conclusions}

This article has mainly focused on the importance of HT crops and Bt crops since these two transgenic technologies cover almost all the global area cultivated with GM crops. Over the past 12 years, biotech crop area has increased more than 67-fold, making GM crops one of the most rapidly adopted farming technologies in modern history (James, 2007). Glyphosate is the world's most used herbicide due to its safety and effectiveness at controlling hundreds of different kinds of weeds. The effectiveness of the herbicide has stimulated seed companies to engineer glyphosateresistant crops and convinced growers to grow them. They have had remarkable ecological and environmental impact in diminishing soil erosion due to reduced cultivation or non-tillage practices. The model has proven so successful that of the transgenic crops planted worldwide in 2006, approximately $80 \%$ were engineered to be glyphosate-resistant. Nevertheless, this success could become a potential failure if modern agriculture becomes too dependent on a single chemical. Some researchers have stated that "glyphosate is as important to world agriculture as penicillin is to human health" (Service, 2007). The comparison is valid because pathogens have grown resistant to penicillin and other antibiotics, and resistance to glyphosate will likely result in an increased appearance of weed resistant biotypes in different production areas, according to several experts (Service, 2007). To preserve the effectiveness of glyphosate as long as possible, several resistance management strategies have been proposed by weed specialists. Among these are rotating crops and using a variety of different herbicides to control weeds, practices that hinder resistant organisms from gaining a foothold in the growers' fields. In practice, this means rotating crops that do not rely on using glyphosate. Another strategy is to use GM crops resistant to other herbicides, such as glufosinate. These GM crops have not done as well in the market as glyphosateresistant crops (GRCs) probably because the herbicide is more expensive and less effective at killing a broad range of weeds. Dicamba, another inexpensive herbicide that has been on the market for four decades, could emerge as a complement to glyphosate. If so, this will allow growers to rotate their crops between varieties resistant to at least two different herbicides, giving farmers an alternative to the continual use of GRCs, which would considerably delay the appearance of weeds resistant to glyphosate. Another approach is to combine, or 'stack', genes for resistance to multiple herbicides in the same plant. According to Nicholas Duck, a crop scientist in North Carolina, "in the future, everything is going toward product stacks" (Service, 2007). For example, Pioneer Hi-Bred (DuPont) recently engineered HT soybean and HT corn with higher levels of glyphosate 
resistance in addition to sulfonylurea resistance (Pioneer Hi-Bred, 2007). One question that arises is whether crops resistant to multiple herbicides will prolong the useful life of glyphosate. Another question is whether all the approaches described above to preserve the effectiveness of glyphosate will be followed by growers in developing countries, where the protocols of resistance management are usually less rigid than in developed countries.

A concern associated with the use of HT crops is the potential introgression of genes from GM crops into wild relatives (i.e. gene flow) and the potential impact of this on natural ecosystems. For gene flow to take place among cultivars and their wild relatives, several barriers have to be overcome, including the presence of cultivars or wild relatives within pollen or seed dispersal range, the ability to produce viable and fertile hybrids, at least partial overlap in flowering time, actual gene flow by pollen or seed, and the establishment of crop genes in the domesticated or wild recipient populations (Gepts and Papa, 2003). Other aspects that affect gene flow are the type of transgene, its insertion site, the density of plants and ecological factors (Felber et al., 2007). A persuasive argument can be made that an herbicide resistance gene should have no fitness advantage in a natural habitat where the herbicide is not used (Stewart et al., 2003), and glyphosate resistance might reduce fitness under non-agricultural conditions (Baucom and Mauricio, 2004), depending upon the mechanism of resistance. However, in contrast with domestication genes, which often make crops less adapted to natural ecosystems, transgenes frequently represent gain of function, which might release wild relatives from constraints that limit their fitness (Gepts and Papa, 2003). Transgenes that might increase the fitness and competitiveness of wild relatives of crops in natural ecosystems include those that confer insect and disease resistance, drought and salt tolerance, which could be important in natural habitats (Stewart et al., 2003).

Cotton and corn with transgenes encoding both insect and herbicide resistance have been approved for commercialization in the USA. However, introgression is not a concern for these two crops in most of the country because they will not interbreed with USA wild species. A reasonable concern exists in geographic locations where there is the potential for transmission of genes to wild relatives (i.e., corn in Mexico, rice in China). A more immediate problem is gene flow from herbicide-resistant crops to non-transgenic crops of the same species. This has already been reported in North America in crops (i.e., canola, rice, and creeping bentgrass) that were meant to be kept transgenic free, and there is a need for technology to prevent introgression from transgenic crops. There are several approaches for mitigation or elimination of introgression of transgenes: (A) Use sterile varieties. For example, Webster et al. (2003) recommended triploid, nonpollen producing or -receiving cultivars of bermudagrass for introduction of herbicidetolerant turf. (B) Utilize isolation requirements for achieving transgene confinement depending on the type and the pollinator activity. For example, non-GM rice showed marked reductions in transgene flow with short spatial isolation (i.e., $6.2 \mathrm{~m}$ ) from $\mathrm{GM}$ rice (Rong et $a l .$, 2007). Pollen-mediated gene flow (PGF) decreased exponentially with distance from HT cotton and low levels of PGF (i.e., $<0.5 \%$ ) were detected at $30 \mathrm{~m}$ (Van Deynze et al., 2005), and $1.5 \mathrm{~km}$ from HT alfalfa (Van Deynze $e t$ $a l ., 2004)$ when pollinated by honeybees. (C) Transformation of the chloroplast genome would prevent or greatly reduce gene flow through pollen flow (Daniell et al., 1998). Chloroplasts are normally inherited maternally, in the same way that organelles such as mitochondria are in animals. This predominantly maternal inheritance has two beneficial effects. First, gene transfer to weedy relatives, which occurs principally through pollen, is reduced. Second, pollen from plants in which the chloroplast genome has been transformed does not represent a toxic risk to non-target species (i.e., the 'Monarch butterfly' controversy), as the detection of paternal plastid transmission occurs very rarely under field conditions (Svab and Maliga, 2007). This has proved to be the case even when the transgene product normally accumulates to a very high level (Slater et al., 2003). The plastid transformation technology looks promising since Monsanto licensed it, and it could be commercially available with 3 to 4 years (Service, 2007). However, this 
technology will likely not solve by itself all the introgression problems derived from the use of GM crops. Other approaches for reducing gene flow have also been documented (Stewart et al., 2003; Cerdeira and Duke, 2006; Gressel, 2007). Combining effective and widespread methods for eliminating gene flow is an important step for preventing the potential environmental impact of transgenic crops, and consequently, increasing the success of GM crops in the future.

The advantages of insect-resistant transgenic plants (Bt crops) have been reviewed in this article. Overall, Bt crops reduced insecticide usage in the USA by 3,700 tons in 2005 , providing benefits for human health and the environment (Sankula, 2006). Yields of Bt cotton and Bt corn have been increased, especially in developing countries. The report that Monarch butterfly larvae were killed after eating pollen from corn plants expressing the $\mathrm{Bt}$ toxin had great impact on public opinion (Losey et al. 1999). However, subsequent field trials indicated that while this is true in laboratory tests, exposure of the larvae to the transgenic pollen is quite low in the natural environment (Sears et al., 2001). The risk to non-target insects from Bt pollen is much less than that from insecticides that would be used if the crop did not contain the Bt trait (Pimentel and Raven, 2000). Overall, Bt crops showed less detrimental effects on non-target species than using conventional insecticides on nontransgenic crops (Marvier et al., 2007). Secondgeneration techniques were launched to the market in 2003 and have limited the expression of the Bt protein only to the leaves, stem or roots, eliminating the toxin protein from pollen. Since there is no insect pest that has developed resistance to Bt crops to date, it appears that the practices developed to delay resistance of pest insects to Bt crops (i.e., high expression levels, refuges and transgene pyramiding, among others) have been successful. It is likely that these resistance strategies will be improved in the future, as well as new transgenic plants expressing novel Cry or other insecticidal proteins, use of synergists and insect digestion inhibitors, stacked genes, and fusion proteins will increase the toxicity and selectivity of $\mathrm{Bt}$ toxins to control the target insects.

Public acceptance is a key issue for further in- troduction of GM crops in those markets where people are reluctant to accept and incorporate this technology, particularly in the European Union. Social, economic and political reasons explain this rejection of transgenic crops that go beyond the scope of this article. It is possible that the public opinion could change if the benefits of GM crops were more tangible. All the GM crops presently available in the market are traits that benefit the farmers ('input traits'), but none of them are benefiting the consumer directly ('output traits'). The classic example of 'output trait' is the case of 'Golden Rice'. This product started to be developed in 1992 and is expected to be commercially released in 2011 in the Philippines and India (Mayer, 2007). From the humanitarian prospective, this 20-year wait for the release of 'Golden Rice' has been harmful if we consider that 124 million children are deficient in vitamin A (Humphrey et al., 1992), and that improved nutrition in vitamin A could prevent 1 to 2 million deaths annually (West et al., 1989). An initial obstacle to the delivery of 'Golden Rice' to its potential beneficiaries was the protection of intellectual property rights (IPRs), with 70 IPRs and technology protection rights belonging to 32 different companies and universities (Slater et al., 2003). However, in practice this obstacle was readily overcome with licensing agreements that allowed the humanitarian use of the relevant IPRs in developing countries. The major delay in deployment of 'Golden Rice' has been due to the regulatory system that required complete redesign of the vectors used, the identification of only a single transgenic event to deregulate, and the exhaustive testing that is required only of transgenic crops (Mayer, 2007). The regulatory system and particularly the Cartagena Protocol on Biosafety and the Convention on Biological Diversity is making very restrictive rules based upon the 'precautionary principle' that results in considerable hurdles for international trade in biotechnology crops (De Greef, 2004), where the only trigger is whether recombinant DNA techniques are employed. Identical traits developed by 'traditional' techniques (i.e., mutation or breeding) do not encounter such hurdles, even though they may have comparable environmental impacts. A sensible approach would be to deregulate biotechnology traits in proportion to their potential risk and in light of experience with both traditional and biotechnology methods of 
genetic improvement (Bradford, 2007; Bradford et al., 2005). The potential benefits of agricultural biotechnology, such as improving nutritional quality or reducing pesticide use, are too great to be withheld from the majority of the world's population due to regulatory issues. As Nobel Peace Price recipient Dr. Norman Borlaug noted (Borlaug, 1997), "this issue goes far beyond economics and regulatory issues; it is also a matter for deep ethical consideration. Fundamentally, the issue is whether small-scale farmers of the developing world also have a right to share in the benefits of biotechnology. If the answer is yes, then what is the role of international and national governments to ensure that this right is met? I believe we must give this matter serious thought". The Public Research and Regulation Foundation has been established to provide an avenue for input from public researchers into the international biotechnology regulatory process (www. pubresreg.org). Seed biotechnology researchers who hope to see the results of their efforts translated into agricultural practice are encouraged to become engaged in this process so that sensible regulatory protocols can guide the safe application of seed biotechnology for agricultural and consumer benefit (Bradford, 2007).

Finally, genetic engineering should not be considered as the 'silver bullet' that will solve all the problems of growers and the worldwide human malnutrition. Instead, it should be regarded as a very powerful tool that will complement traditional plant breeding. It is expected that 'realistic' predictive models and risk assessment for evaluating GM crops in both laboratory and field conditions will be fine tuned in the future in order to optimize benefits and time while reducing potential risks. The introduction of GM crops should be critically analyzed 'case by case' due to the complexity of the biological issues and to avoid irreversible damage to ecosystems, especially by gene flow. In order to determine the impact of the introduction of a GM crop, benefits and risks should be carefully analyzed in each case and compared to those associated with current practices. However, the current international regulatory system of GM crops is based on the 'precautionary principle' that only considers the risks of using GM crops. Instead, it should evaluate the risks of utilizing GM crops relative to their benefits, and compare them with the traditional methods of genetic improvement.

\section{Resumen}

Los cultivos genéticamente modificados (GM) fueron introducidos a mediados de los noventa y hay actualmente dos tecnologías principales de transgénicos en el mercado, los cultivos tolerantes a los herbicidas (HT) y los cultivos resistentes a insectos (cultivos Bacillus thuringiensis (Bt)). Los cultivos HT han simplificado y reducido los costos de manejo de malezas a los productores $y$ han favorecido el medio ambiente. Sin embargo, existe inquietud por el desarrollo potencial de malezas resistentes al glifosato, el principal herbicida empleado en cultivos HT. Una segunda trascendental preocupación asociada al uso de cultivos HT es la introgresión potencial de genes desde los cultivos GM a las especies cercanas nativas (flujo génico) y su impacto en los ecosistemas. Los cultivos Bt han incrementado los rendimientos, reducido el uso de insecticidas, lo que ha consiguientemente beneficiado la salud de los productores y el ambiente. Sin embargo, el desarrollo potencial de resistencia de los insectos a las toxinas $\mathrm{Bt}$ y el daño indirecto de las toxinas $\mathrm{Bt}$ a especies no albo a éstas constituyen problemas relevantes relacionados al uso de cultivos Bt. Diferentes estrategias para mitigar y eliminar los problemas asociados al uso de transgénicos son discutidas en el artículo. La próxima etapa en biotecnología vegetal es la introducción de semillas mejoradas en su composición nutritiva, lo que va a beneficiar a los consumidores directamente.

Palabras clave: Cultivos Bt, flujo génico, cultivos genéticamente modificados, glifosato, Arroz Dorado, cultivos tolerantes a herbicidas, cultivos transgénicos.

\section{Acknowledgements}

The author thanks the Western Regional Seed Physiology Research Group, a group of seed companies that support research at UC Davis, for funding. I am very grateful of Kent J. Bradford, Dario Cantu, and Cristóbal Uauy, for their constructive comments on the manuscript. 


\section{References}

Abel, P.P., R.S. Nelson, B. De, N. Hoffman, and S.G. Rogers. 1986. Delay of disease development in transgenic plants that express the tobacco mosaic virus coat protein gene. Science 232:738-743.

Alfonso-Rubi, J., F. Ortego, P. Castanera, P. Carbonero, and I. Diaz. 2003. Transgenic expression of trypsin inhibitor CMe from barley in indica and japonica rice, confers resistance to the rice weevil Sitophilus oryzae. Transgenic Res. 12:23-31.

Bano-Maqbool, S., S. Riazuddin, N. Thi Loc, A.M.R. Gatehouse, J.A. Gatehouse, and P. Christou. 2001. Expression of multiple insecticidal genes confers broad resistance against a range of different rice pests. Mol. Breed. 7:85-93.

Bates, S.L., J.Z. Zhao, R.T. Roush, and A.M. Shelton. 2005. Insect resistance management in GM crops: past, present and future. Nat. Biotechnol. 23:57-62.

Baucom, R.S., and R. Mauricio. 2004. Fitness costs and benefits of novel herbicide tolerance in a noxious weed. Proc. Natl. Acad. Sci. USA 101:13386-13390.

Beachy, R.N. 1997. Mechanisms and applications of pathogen-derived resistance in transgenic plants. Curr. Opin. Biotechnol. 8:215-220.

Behrens, M.R., N. Mutlu, S. Chakraborty, R. Dumitru, W.Z. Jiang, B.J. Lavallee, P.L. Herman, T.E. Clemente, and D.P. Weeks. 2007. Dicamba resistance: enlarging and preserving biotechnology-based weed management strategies. Science 316:1185-1188.

Borlaug, N.E. 1997. Feeding a world of 10 billion people: the miracle ahead. Lecture presented at De Montfort University, Leicester, United Kingdom. May 6, 1997.

Bradford, K.J., A. Van Deynze, N. Gutterson, W. Parrott, and S.H. Strauss. 2005. Regulating transgenic crops sensibly: lessons from plant breeding, biotechnology and genomics. Nat. Biotechnol. 23:439-444.

Bradford, K.J. 2007. Seed biotechnology: translating promise into practice. Pages 130-138. In: S.W. Adkins, S. Ashmore, and S.C. Navie (eds.). Seeds: Biology, Development and Ecology. CAB International, Wallingford, UK.

Brini, F., M. Hanin, I. Mezghani, G.A. Berkowitz, and K. Masmoudi. 2007. Overexpression of wheat $\mathrm{Na}+\mathrm{H}+$ antiporter TNHX1 and $\mathrm{H}+-$ pyrophosphatase TVP1 improve salt- and drought-stress tolerance in Arabidopsis thaliana plants. J. Exp. Bot. 58:301-308.

Carpenter, J., and L. Gianessi. 1999. Herbicide tolerant soybeans: why growers are adopting Roundup Ready varieties. Ag. Bio. Forum 2:65-72.
Carpenter, J., A. Felsot, T. Goode, and M. Hamming. 2002. Comparative environmental impacts of biotechnology-derived and traditional soybean, corn, and cotton crops. Ames, IO, Council for Agricultural Science and Technology, $4 \mathrm{p}$.

Castle, L.A., G. Wu, and D. McElroy. 2006. Agricultural input traits: past, present and future. Curr. Opin. Biotechnol. 17:105-112.

Cattaneo, M.G., C. Yafuso, C. Schmidt, C.Y. Huang, M. Rahman, C. Olson, C. Ellers-Kirk, B.J. Orr, S.E. Marsh, L. Antilla, P. Dutilleul, and Y. Carriere. 2006. Farm-scale evaluation of the impacts of transgenic cotton on biodiversity, pesticide use, and yield. Proc. Natl. Acad. Sci. USA 103:7571-7576.

Cerdeira, A.L., and S.O. Duke. 2006. The current status and environmental impacts of glyphosateresistant crops: a review. J. Environ. Qual. 35:1633-1658.

Chattopadhyay, A., N.B. Bhatnagar, and R. Bhatnagar. 2004. Bacterial insecticidal toxins. Crit. Rev. Microbiol. 30:33-54.

Chen, L.J., D.S. Lee, Z.P. Song, H.S. Suh, and B.R. Lu. 2004. Gene flow from cultivated rice (Oryza sativa) to its weedy and wild relatives. Ann. Bot. (Lond) 93:67-73.

Chen, J., G. Hua, J.L. Jurat-Fuentes, M.A. Abdullah, and M.J. Adang. 2007. Synergism of Bacillus thuringiensis toxins by a fragment of a toxinbinding cadherin. Proc. Natl. Acad. Sci. USA 104:13901-13906.

Chilcutt, C.F., and B.E. Tabashnik. 2004. Contamination of refuges by Bacillus thuringiensis toxin genes from transgenic maize. Proc. Natl. Acad. Sci. USA 101:7526-7529.

Christou, P., T. Capell, A. Kohli, J.A. Gatehouse, and A.M. Gatehouse. 2006. Recent developments and future prospects in insect pest control in transgenic crops. Trends Plant Sci. 11:302-308.

Crickmore, N., D.R. Zeigler, E. Schnepf, J. Van Rie, D. Lereclus, J. Baum, A. Bravo, and D.H. Dean. 2007. Bacillus thuringiensis toxin nomenclature.www.lifesci.sussex.ac.uk/Home/ Neil_Crickmore/Bt/

Dangl, J.L., and J.D. Jones. 2001. Plant pathogens and integrated defence responses to infection. Nature 411:826-833.

Daniell, H., R. Datta, S. Varma, S. Gray, and S.B. Lee. 1998. Containment of herbicide resistance through genetic engineering of the chloroplast genome. Nat. Biotechnol. 16:345-348.

Daniell, H., P.O. Wiebe, and A.F. Millan. 2001. Antibiotic-free chloroplast genetic engineering - an environmentally friendly approach. Trends Plant Sci. 6:237-239.

Daniell, H., and A. Dhingra. 2002. Multigene engineering: dawn of an exciting new era in biotechnology. Curr. Opin. Biotechnol. 13:136-141. 
De Greef, W. 2004. The Cartagena Protocol and the future of agbiotech. Nat. Biotechnol. 22:811-812.

De Maagd, R.A., D. Bosch, and W. Stiekema. 1999. Bacillus thuringiensis toxin-mediated insect resistance in plants. Trends Plant Sci. 4:9-13.

De Maagd, R.A., A. Bravo, C. Berry, N. Crickmore, and H.E. Schnepf. 2003. Structure, diversity, and evolution of protein toxins from sporeforming entomopathogenic bacteria. Annu. Rev. Genet. 37:409-433.

Dezar, C.A., G.M. Gago, D.H. González, and R.L. Chan. 2005. Hahb-4, a sunflower homeoboxleucine zipper gene, is a developmental regulator and confers drought tolerance to Arabidopsis thaliana plants. Transgenic Res. 14:429-440.

Dill, G.M. 2005. Glyphosate-resistant crops: history, status and future. Pest Manag. Sci. 61:219-224.

Diretto, G., S. Al-Babili, R. Tavazza, V. Papacchioli, P. Beyer, and G. Giuliano. 2007. Metabolic engineering of potato carotenoid content through tuber-specific overexpression of a bacterial mini-pathway. PLoS ONE 4:e350.

Duke, S.O. 2005. Taking stock of herbicide-resistant crops ten years after introduction. Pest Manag Sci. 61:211-218.

Duke, S.O., S.R. Baerson, and A.M. Rimando. 2003. Herbicides: Glyphosate. In J.R. Plimmer, D.W. Gammon, and N.N. Ragsdale ed. Encycl. of Agrochemicals. John Wiley and Sons, New York, NY, USA.

Ebert, E., K.H. Leist, and D. Mayer. 1990. Summary of safety evaluation toxicity studies of glufosinate ammonium. Food Chem. Toxicol. 28:339-349.

Ellis, J.M., J.L. Griffin, S.D. Linscombe, and E.P. Webster. 2003. Rice (Oryza sativa) and corn (Zea mays) response to simulated drift of glyphosate and glufosinate. Weed Technol. 17:452-460.

FAO. 2004. The State of Food and Agriculture. Food and Agriculture Organization of the United Nations. FAO, Rome.

Farinós, G.P., M. de la Poza, P. Hernández-Crespo, F. Ortego, and P. Castañera. 2004. Resistance monitoring of field populations of the corn borers Sesamia nonagrioides and Ostrinia nubilalis after 5 years of $\mathrm{Bt}$ maize cultivation in Spain. Entomol. Exp. Appl. 110:23-30.

Felber, F., G. Kozlowski, N. Arrigo, and R. Guadagnuolo. 2007. Genetic and ecological consequences of transgene flow to the wild flora. Adv. Biochem. Eng. Biotechnol. 107:173-205.

Fernández-Cornejo, J., and W. McBride. 2002. USDA Economic Research Service: Adoption of Genetically Engineered Crops in the US: Data Glossary. USDA, Washington, DC. www. ers.usda.gov/Data/biotechcrops/glossary.htm (Accessed: October, 2007).

Fernández-Cornejo, J. 2007. USDA Economic
Research Service: Adoption of Genetically Engineered Crops in the United States. USDA, Washington, DC. www.ers.usda.gov/Data/ biotechcrops/ (Accessed: October, 2007).

Ferreira, S.A., K.Y. Pitz, R. Manshardt, F. Zee, M. Fitch, and D. Gonsalves. 2002. Virus coat protein transgenic papaya provides practical control of papaya ringspot virus in Hawaii. Plant Disease 86:101-105.

Ferry, N., M.G. Edwards, J. Gatehouse, T. Capell, P. Christou, and A.M. Gatehouse. 2006. Transgenic plants for insect pest control: a forward looking scientific perspective. Transgenic Res. 15:13-19.

Flowers, T.J. 2004. Improving crop salt tolerance. J. Exp. Bot. 55:307-319.

Fox, J.L. 2003. Resistance to Bt toxin surprisingly absent from pests. Nat. Biotechnol. 21:958-959.

Fuchs, M., E.M. Chirco, and D. Gonsalves. 2004. Movement of coat protein genes from a virusresistant transgenic squash into a free-living relative. Environ. Biosaf. Res. 3:5-16.

Fuchs, M., and D. Gonsalves. 2007. Safety of virusresistant transgenic plants two decades after their introduction: lessons from realistic field risk assessment studies. Annu. Rev. Phytopathol. 45:173-202.

Gepts, P., and R. Papa. 2003. Possible effects of (trans)gene flow from crops on the genetic diversity from landraces and wild relatives. Environ. Biosafety Res. 2:89-103.

Gianessi, L.P. 2005. Economic and herbicide use impacts of glyphosate-resistant crops. Pest Manag. Sci. 61:241-245.

Gonsalves, D. 1998. Control of papaya ringspot virus in papaya: a case study. Annu. Rev. Phytopathol. 36:415-437.

Gonsalves, D., A. Vegas, V. Prasartsee, R. Drew, J.Y. Suzuki, and S. Tripathi. 2006. Developing papaya to control papaya ringspot virus by transgenic resistance, intergeneric hybridization, and tolerance breeding. Plant Breed. Rev. 26:35-78.

Graham,I.A., T.Larson, andJ.A.Napier.2007.Rational metabolic engineering of transgenic plants for biosynthesis of omega-3 polyunsaturates. Curr. Opin. Biotechnol. 18:142-147.

Gressel, J. 2005. Problems in qualifying and quantifying assumptions in plant protection models: resultant simulations can be mistaken by a factor of million. Crop. Prot. 24:1007-1015.

Gressel, J. 2007. Failsafe mechanisms for preventing gene flow and organism dispersal of enhanced microbial biocontrol agents. Pages 353-362. In: M. Vurro, and J. Gressel (eds.), Novel Biotechnologies for Biocontrol Agent Enhancement and Management. NATO Security through Science Series. Springer Netherlands.

Griffiths, A.J.F., S.R. Wessler, R.C. Lewontin, W.M. 
Gelbart, D.T. Suzuki, and J.H. Miller. 2005. Introduction to Genetic Analysis. 8th ed. W.H. Freeman, New York.

Gruden, K., B. Strukelj, T. Popovic, B. Lenarcic, T. Bevec, J. Brzin, I. Kregar, J. Herzog-Velikonja, W.J. Stiekema, D. Bosch, and M.A. Jongsma. 1998. The cysteine protease activity of Colorado potato beetle (Leptinotarsa decemlineata Say) guts, which is insensitive to potato protease inhibitors, is inhibited by thyroglobulin type-1 domain inhibitors. Insect Biochem. Mol. Biol. 28:549-560.

Halford, N.G. 2006. From primitive selection to genetic modification, ten thousand years of plant breeding. Pages 3-27. In: N.G. Halford (ed.). Plant Biotechnology: Current and Future Applications of Genetically Modified Crops. J. Wiley, Chichester, England.

Heap, I., H. Glick, L. Glasgow, and H. Beckie. 2006. International Survey of Herbicide Resistant Weeds, Corvallis, OR, USA. www.weedscience. org/glyphosate.gif (Accessed: October, 2007).

Höfte, H., and H.R. Whiteley. 1989. Insecticidal crystal proteins of Bacillus thuringiensis. Microbiol Rev. 53:242-255.

Hossain, F., C.E. Pray, Y. Lu, J. Huang, C. Fan, and R. Hu. 2004. Genetically modified cotton and farmers' health in China. Int. J. Occup. Environ. Health 10:296-303.

Huang, J., S. Rozelle, C. Pray, and Q. Wang. 2002. Plant biotechnology in China. Science 295:674-676.

Huang, J., R. Hu, S. Rozelle, and C. Pray. 2005. Insect-resistant GM rice in farmers' fields: assessing productivity and health effects in China. Science 308:688-690.

Huang, G., R. Allen, E.L. Davis, T.J. Baum, and R.S. Hussey. 2006. Engineering broad rootknot resistance in transgenic plants by RNAi silencing of a conserved and essential root-knot nematode parasitism gene. Proc. Natl. Acad. Sci. USA 103:14302-14306.

Humphrey, J.H., K.P. West, Jr., and A. Sommer. 1992. Vitamin A deficiency and attributable mortality among under-5-year-olds. Bull World Health Organ 70:225-232.

Jackson, R.E., J.R. Bradley, and J.W. Duyn. 2004. Performance of feral and CrylAc-selected Helicoverpa zea (Lepidoptera: Noctuidae) strains on transgenic cottons expressing one or two Bacillus thuringiensis ssp. kurstaki proteins under greenhouse conditions. J. Entomol. Sci. 39:46-55.

James, C. 2007. Global Status of Commercialized Biotech/GM Crops: 2007. ISAAA Briefs No. 37. The International Service for the Acquisition of Agri-biotech Applications, Ithaca, NY. www. isaaa.org/resources/publications/briefs/37/ executivesummary/default.html (Accessed: April, 2008).
Knowles, B.H., and J.A.T. Dow. 1993. The crystal delta-endotoxins of Bacillus thuringiensis - models for their mechanism of action on the insect gut. BioEssays 15:469-476.

Lauer, J.G., and J. Wedberg. 1999. Grain yield of initial Bt corn hybrid introductions to farmers in the northern Corn Belt. J. of Prod. Agric. 12:373-376.

Légère, A. 2005. Risks and consequences of gene flow from herbicide-resistant crops: canola (Brassica napus L) as a case study. Pest Manag. Sci. 61:292-300.

Losey, J.E., L.S. Rayor, and M.E. Carter. 1999. Transgenic pollen harms monarch larvae. Nature 399:214.

Lutz, K.A., and P. Maliga. 2007. Construction of marker-free transplastomic plants. Curr. Opin. Biotechnol. 18:107-114.

MacIntosh, S.C., T.B. Stone, S.R. Sims, P.L. Hunst, J.T. Greenplate, P.G. Marrone, F.J. Perlak, D.A. Fischhoff, and R.L. Fuchs. 1990. Specificity and efficacy of purified Bacillus thuringiensis proteins against agronomically important insects. J. Invertebr. Pathol. 56:258-266.

Martínez, M., Z. Abraham, P. Carbonero, and I. Díaz. 2005. Comparative phylogenetic analysis of cystatin gene families from arabidopsis, rice and barley. Mol. Genet. Genomics 273:423-432.

Marvier, M., C. McCreedy, J. Regetz, and P. Kareiva. 2007. A meta-analysis of effects of Bt cotton and maize on nontarget invertebrates. Science 316:1475-1477.

Mayer, J. 2007. Golden Rice and nutritional enhancement of seeds. Lecture presented at the University of California, Davis, United States. September 19, 2007. www.goldenrice.org

Mehlo, L., D. Gahakwa, P.T. Nghia, N.T. Loc, T. Capell, J.A. Gatehouse, A.M. Gatehouse, and P. Christou. 2005. An alternative strategy for sustainable pest resistance in genetically enhanced crops. Proc. Natl. Acad. Sci. USA 102:7812-7816.

Mendelsohn, M., J. Kough, Z. Vaituzis, and K. Matthews. 2003. Are Bt crops safe? Nat. Biotechnol. 21:1003-1009.

Mirkov, T.E. 2003. The molecular basis of genetic modification and improvement of crops. Pages 124-151. In: M.J. Chrispeels, and D.E. Sadava (eds.). Plants, Genes, and Crop Biotechnology. 2nd ed. Jones and Bartlett Publisher, Boston. USA

Mondal, K.K., R.C. Bhattacharya, K.R. Koundal, and S.C. Chatterjee. 2007. Transgenic Indian mustard (Brassica juncea) expressing tomato glucanase leads to arrested growth of Alternaria brassicae. Plant Cell Rep. 26:247-252.

Murai, N., D.W. Sutton, M.G. Murray, J.L. Slightom, D.J. Merlo, N.A. Reichert, C. Sengupta-Gopalan, C.A. Stock, R.F. Barker, and et al. 1983. 
Phaseolin gene from bean Phaseolus vulgaris is expressed after transfer to sunflower via tumor inducing plasmid vectors. Science 222:476-482.

Ohsato, S., T. Ochiai-Fukuda, T. Nishiuchi, N. Takahashi-Ando, S. Koizumi, H. Hamamoto, T. Kudo, I. Yamaguchi, and M. Kimura. 2007. Transgenic rice plants expressing trichothecene 3-O-acetyltransferase show resistance to the Fusarium phytotoxin deoxynivalenol. Plant Cell Rep. 26:531-538.

Outchkourov, N.S., W.J. de Kogel, G.L. Wiegers, M. Abrahamson, and M.A. Jongsma. 2004. Engineered multidomain cysteine protease inhibitors yield resistance against western flower thrips (Frankliniella occidentalis) in greenhouse trials. Plant Biotechnol. J 2:449-458.

Padgette, S.R., D.B. Re, G.F. Barry, D.E. Eichholtz, X. Delannay, R.l. Fuchs, G.M. Kishore, and R.T. Fraley. 1996. New weed control opportunities: development of soybeans with Roundup ReadyTM gene. Pages 33-84. In: S.O. Duke (ed.). Herbicideresistant Crops: Agricultural, Environmental, Economic, Regulator, and Technical Aspects. CRC Press, Boca Raton, Fl, USA.

Paine, J.A., C.A. Shipton, S. Chaggar, R.M. Howells, M.J. Kennedy, G. Vernon, S.Y. Wright, E. Hinchliffe, J.L. Adams, A.L. Silverstone, and R. Drake. 2005. Improving the nutritional value of Golden Rice through increased pro-vitamin A content. Nat. Biotechnol. 23:482-487.

Pimentel, D.S., and P.H. Raven. 2000. Bt corn pollen impacts on nontarget lepidoptera: assessment of effects in nature. Proc. Natl. Acad. Sci. USA 97:8198-8199.

Pioneer Hi-Bred International official webpage. 2007. Product development of corn and soybean crops. www.pioneer.com/web/site/ portalmenuitem.c4957a56c0ff1418bc0c0a03d1 0093a0/ (Accessed: November, 2007).

Pitz, K., S. Ferreira, R. Mau, and D. Gonsalves. 1994. Papaya cross protection: the nearcommercialization experience on Oahu. Proceedings: $30^{\text {th }}$ Annu. Hawaii Papaya Industry Assoc. Conf., September 23-34, 1994, Maui, Hawaii. p. 4-6.

Powles, S.B. 2008. Evolved glyphosate-resistant weeds around the world: lessons to be learnt. Pest. Manag Sci. 64:360-365.

Pray, C.E., J. Huang, R. Hu, and S. Rozelle. 2002. Five years of Bt cotton in China - the benefits continue. Plant J. 31:423-430.

Prins, M., M. Laimer, E. Noris, J. Schubert, M. Wassenegger, and M. Tepfer. 2008. Strategies for antiviral resistance in transgenic plants. Mol. Plant Pathol. 9:73-83.

Qaim, M., and D. Zilberman. 2003. Yield effects of genetically modified crops in developing countries. Science 299:900-902.
Qi, B., T. Fraser, S. Mugford, G. Dobson, O. Sayanova, J. Butler, J.A. Napier, A.K. Stobart, and C.M. Lazarus. 2004. Production of very long chain polyunsaturated omega-3 and omega-6 fatty acids in plants. Nat. Biotechnol. 22:739-745.

Racman, D.S., K. McGeachy, B. Reavy, B. Strukelj, J. Zel, and H. Barker. 2001. Strong resistance to potato tuber necrotic ringspot disease in potato induced by transformation with coat protein gene sequences from an NTN isolate of Potato virus Y. Ann. of Appl. Biol. 139:269-275.

Rein, D., and K. Herbers. 2006. Enhanced nutritional value of food crops. Pages 91-117. In: N.G. Halford (ed.). Plant Biotechnology: Current and Future Applications of Genetically Modified Crops. J. Wiley, Chichester, England.

Romeis, J., M. Meissle, and F. Bigler. 2006. Transgenic crops expressing Bacillus thuringiensis toxins and biological control. Nat. Biotechnol. 24:63-71.

Rommens, C.M., and G.M. Kishore. 2000. Exploiting the full potential of disease-resistance genes for agricultural use. Curr. Opin. Biotechnol. 11:120-125.

Rong, J., B.R. Lu, Z. Song, J. Su, A.A. Snow, X. Zhang, S. Sun, R. Chen, and F. Wang. 2007. Dramatic reduction of crop-to-crop gene flow within a short distance from transgenic rice fields. New Phytol. 173:346-353.

Roush, R.T. 1998. Two-toxin strategies for management of insecticidal transgenic crops: can pyramiding succeed where pesticide mixtures have not? Phil. Trans. R. Soc. Lond. B. 353:1777-1786.

Sanford, J.C., and S.A. Johnston. 1985. The concept of parasite-derived resistance: Deriving resistance genes from the parasite's own genome. J. Theor. Biol. 113:395-405.

Sankula, S. 2006. Quantification of the impacts on US agriculture of the biotechnology-derived crops planted in 2005. National Center for Food and AgriculturalPolicy, Washington,DC.www.ncfap. org/whatwedo/pdf/2005biotechExecSummary. pdf (Accessed: October, 2007).

Sanvido, O., J. Romeis, andF. Bigler. 2007. Ecological impacts of genetically modified crops: ten years of field research and commercial cultivation. Adv. Biochem. Eng. Biotechnol. 107:235-278.

Sears, M.K., R.L. Hellmich, D.E. Stanley-Horn, K.S. Oberhauser, J.M. Pleasants, H.R. Mattila, B.D. Siegfried, and G.P. Dively. 2001. Impact of Bt corn pollen on monarch butterfly populations: a risk assessment. Proc. Natl. Acad. Sci. USA 98:11937-11942.

Service, R.F. 2007. Agbiotech. A growing threat down on the farm. Science 316:1114-1117.

Shou, H., P. Bordallo, and K. Wang. 2004. Expression of the Nicotiana protein kinase (NPK1) 
enhanced drought tolerance in transgenic maize. J. Exp. Bot. 55:1013-1019.

Slater, A., N.W. Scott, and M.R. Fowler. 2003. Plant Biotechnology: The Genetic Manipulation of Plants. Oxford University Press. Oxford, NY, USA.

Smith, C.J.S, C.F. Watson, J. Ray, C.R. Bird, W. Schuch, and D.Grierson. 1988. Antisense inhibition of polygalacturonase expression in transgenic tomatoes. Nature 334:724-726.

Stevens, J. T., and D.D. Sumner. 1991. Herbicides. Pages 1317-1408. In: W.J (Jr.) Hayes, and E.R. (Jr.) Laws. (eds.). Handbook of Pesticide Toxicology. Academic Press, NY, USA.

Stewart, C.N., Jr., M.D. Halfhill, and S.I. Warwick. 2003. Transgene introgression from genetically modified crops to their wild relatives. Nat. Rev. Genet. 4:806-817.

Sudarshana, M.R., G. Roy, and B.W. Falk. 2006. Methods for engineering resistance to plant viruses. Methods Mol. Biol. 354:183-196.

Svab, Z., and P. Maliga. 2007. Exceptional transmission of plastids and mitochondria from the transplastomic pollen parent and its impact on transgene containment. Proc. Nat.l Acad. Sci. USA 104:7003-7008.

Tabashnik, B.E. 1994. Evolution of resistance to Bacillus thuringiensis. Annu. Rev. of Entomol. 39:47-49.

Tabashnik, B.E., T.J. Dennehy, and Y. Carriere. 2005. Delayed resistance to transgenic cotton in pink bollworm. Proc. Natl. Acad. Sci. USA 102:15389-15393.

Tabashnik, B.E., A.J. Gassman, D.W. Crowder, and Y. Carriere. 2008. Insect resistance to $\mathrm{Bt}$ crops: evidence versus theory. Nat. Biotechnol. 26:199-202.

Thompson, C.J., N.R. Movva, R. Tizard, R. Crameri, J.E. Davies, M. Lauwereys, and J. Botterman. 1987. Characterization of the herbicideresistance gene bar from Streptomyces hygroscopicus. Embo. J. 6:2519-2523.

Töpfer, R., N. Martini, and J. Schell. 1995. Modification of Plant Lipid Synthesis. Science 268:681-686.

Van Deynze, A., Putnam, D.H., Orloff, S., Lanini, T., Canevari, M., Vargas, R., Hembree, K., Mueller, S., and L. Teuber. 2004. Roundup Ready Alfalfa: An Emerging Technology. Division of Agriculture and Natural Resources. University of California, Davis. Publication 8153. http://alfalfa.ucdavis.edu.

Van Deynze, A., Sundstrom, F.J., and K.J Bradford. 2005. Pollen-mediated gene flow in California cotton depends on pollinator activity. Crop Sci. 45:1565-1570.

Van Rie, J., S. Jansens, H. Hofte, D. Degheele, and H. Van Mellaert. 1990. Receptors on the brush border membrane of the insect midgut as determinants of the specificity of Bacillus thuringiensis delta-endotoxins. Appl. Environ. Microbiol. 56:1378-1385.

Watrud, L.S., E.H. Lee, A. Fairbrother, C. Burdick, J.R. Reichman, M. Bollman, M. Storm, G. King, and P.K. Van de Water. 2004. Evidence for landscape-level, pollen-mediated gene flow from genetically modified creeping bentgrass with CP4 EPSPS as a marker. Proc. Natl. Acad. Sci. USA 101:14533-14538.

Webster, T.M., C.W. Bednarz, and W.W. Hanna. 2003. Sensitivity of triploid hydrid bermudagrass cultivars and common bermudagrass to postemergence herbicides. Weed Technol. 17:509-515.

West, K.P., Jr., G.R. Howard, and A. Sommer. 1989. Vitamin A and infection: public health implications. Annu. Rev. Nutr. 9:63-86.

West, K.P., and I. Darnton-Hill. 2001. Vitamin A deficiency. Pages 267-306. In: R.D. Semba, and M.W. Bloem (eds.). Nutrition and Health in Developing Countries. Humana Press, Totowa, NJ, USA.

Williams, G.M., R. Kroes, and I.C. Munro. 2000. Safety evaluation and risk assessment of the herbicide Roundup and its active ingredient, glyphosate, for humans. Regul. Toxicol. Pharmacol. 31:117-165.

Williamson, V.M. 1998. Root-knot nematode resistance genes in tomato and their potential for future use. Annu. Rev. Phytopathol. 36:277-293.

Williamson, V.M., and H.K. Kaya. 2003. Sequence of a symbiont. Nat. Biotechnol. 21:1294-1295.

Ye, X., S. Al-Babili, A. Kloti, J. Zhang, P. Lucca, P. Beyer, and I. Potrykus. 2000. Engineering the provitamin A (beta-carotene) biosynthetic pathway into (carotenoid-free) rice endosperm. Science 287:303-305.

Yeum, K.J., and R.M. Russell. 2002. Carotenoid bioavailability and bioconversion. Annu. Rev. Nutr. 22:483-504.

Yu, C.G., M.A. Mullins, G.W. Warren, M.G. Koziel, and J.J. Estruch. 1997. The Bacillus thuringiensis vegetative insecticidal protein Vip3A lyses midgut epithelium cells of susceptible insects. Appl. Environ. Microbiol. 63:532-536.

Zhang, H.X., and E. Blumwald. 2001. Transgenic salttolerant tomato plants accumulate salt in foliage but not in fruit. Nat. Biotechnol. 19:765-768.

Zhang, H.X., J.N. Hodson, J.P. Williams, and E. Blumwald. 2001. Engineering salt-tolerant Brassica plants: characterization of yield and seed oil quality in transgenic plants with increased vacuolar sodium accumulation. Proc. Natl. Acad. Sci. USA 98:12832-12836.

Zhu-Salzman, K., J.E. Ahn, R.A. Salzman, H. Koiwa, R.E. Shade, and S. Balfe. 2003. Fusion of a soybean cysteine protease inhibitor and a legume lectin enhances anti-insect activity synergistically. Agric. and Forest Entomol. 5:317-323 